\title{
IMOBILISASI HASIL SAMPING PENGOLAHAN LIMBAH CAIR LABORATORIUM KIMIA MENJADI BATU BATA UNTUK KEAMANAN PENYIMPANAN
}

\author{
Taufan Ratri Harjanto*1, Saipul Bahri² \\ Politeknik Negeri Cilacap, Teknik Pengendalian Pencemaran Lingkungan
}

\begin{abstract}
Background: The wastewater treatment plant will produce sludge which is discharged directly into the environment can give rise to environmental risk and the health of humans and other living things. The research purposes are to produce brick from immobilization from by-products (sludge) that are effective, easy and environmentally friendly. Methods: The study was divided into three stages: (1) initial identification, (2) design and (3) interpretation of results and conclusions. Results: The analysis of bricks made based on the ratio of binder and sludge by 1:1,2:1 and 3: 1, the 16 parameters tested guided by Republic of Indonesia Minister of Environment Regulation number 5 of 2014 Concerning Wastewater Quality Standards, Annex XLVII give : there are two parameters that do not the quality standards: (1) Total Dissolved Solids (TDS) is 4200 $m g / l$ (sample A, ratio of binder and sludge 1:1) and (2) the pH parameter is more than 9 (sample $A, B, C$, and E). Conclusion: Sludge, stored in the form of bricks is safe.
\end{abstract}

Keywords: Immobilization, Liquid Waste, Sludge, By-Product, Brick

PENDAHULUAN

Penggunaan bahan kimia pada aktifitas di laboratorium akan menghasilkan produk berupa limbah. Limbah laboratorium tersebut harus dikelola secara mandiri atau diserahkan kepada pihak ketiga untuk pengelolaannya, hal ini sesuai dengan amanah Undang-Undang Republik Indonesia Nomor 32 Tahun 2009 tentang Perlindungan dan Pengelolaan Lingkungan Hidup. Jenis-jenis bahan kimia yang biasanya digunakan di laboratorium kimia tersebut berupa: bahan organik maupun bahan anorganik yang bersifat asam maupun basa. Meskipun kapasitas limbah laboratorium ini relatif kecil jika dibandingkan dengan skala industri namun kandungan bahan pencemarnya sangat beragam dan termasuk golongan limbah bahan berbahaya dan beracun (B3). Karakteristik limbah dari hasil kegiatan laboratorium ini berpotensi mengandung bahan dengan kategori B3 sehingga diperlukan penanganan khusus antara lain dengan instalasi pengolahan air limbah (IPAL).

Instalasi pengolahan air limbah tersebut disamping menghasilkan produk berupa hasil olahan cair akan menghasilkan hasil samping (by-product) berupa padatan / sludge. Masalah akan timbul apabila sludge tersebut dibuang ke lingkungan tanpa ada penanganan lanjut pasti akan menimbulkan risiko terhadap kesehatan manusia dan lingkungannya.

Pada penelitian sebelumnya yang dilakukan di Politeknik Negeri Cilacap, by-product dari pengolahan limbah laboratorium, limbah cair yang dihasilkan 
laboratorium kimia relatif sedikit, akan tetapi by-product ini mengadung bahanbahan yang dapat mencemari lingkungan apabila tidak dikelola lebih lanjut. Perlunya pengolahan limbah secara holistik disetiap laboratorium yang dalam operasionalnya menggunakan bahan kimia merupakan kebutuhan prioritas untuk diselesaikan. Pengolahan limbah byproduct tersebut dapat dilakukan dengan cara imobilisasi menjadi produk padat diharapkan akan memberikan solusi dari permasalahan yang ada.

Tujuan dari penelitian ini untuk menghasilkan produk berupa batu bata dari imobilisasi limbah cair produk samping pengolahan limbah laboratorium kimia yang efektif, mudah dan ramah lingkungan.

\section{METODE PENELITIAN}

Kegiatan dalam penelitian yang dilakukan ini dibagi menjadi tiga tahap, yaitu: tahap identifikasi awal, tahap desain pengolah limbah cair dan tahap interpretasi hasil dan simpulan.
Pada tahap identifikasi awal, dilakukan identifikasi limbah cair laboratorium berdasarkan karakteristik bahan dan jejak rekam penelitian yang pernah dilakukan. Untuk identifikasi awal limbah cair diambil di Laboratorium Kimia Teknik Pengendalian Pencemaran Lingkungan Politeknik Negeri Cilacap.

Pada tahap desain pengolah limbah cair, pendekatan yang dilakukan adalah sesuai dengan konsep green technology yaitu menghilangkan bahan pencemar yang tidak menimbulkan pencemaran baru dari kegiatan yang dilakukan. Bahanbahan pembantu yang digunakan berupa koagulan, sand filter dan adsorber dapat digunakan kembali sesuai dengan konsep imobilisasi bahan buangan yang aman dan ramah bagi lingkungan. Tahap desain pengolah limbah cair adalah dengan menggabungkan berbagai alat pengolahan limbah cair. Susunan alat yang efektif pada penelitian sebelumnya terdiri dari: koagulasi, reaktor asam basa, elektrokoagulasi, adsorbsi, fitoremediasi, dan bio indikator, seperti pada Gambar 1.

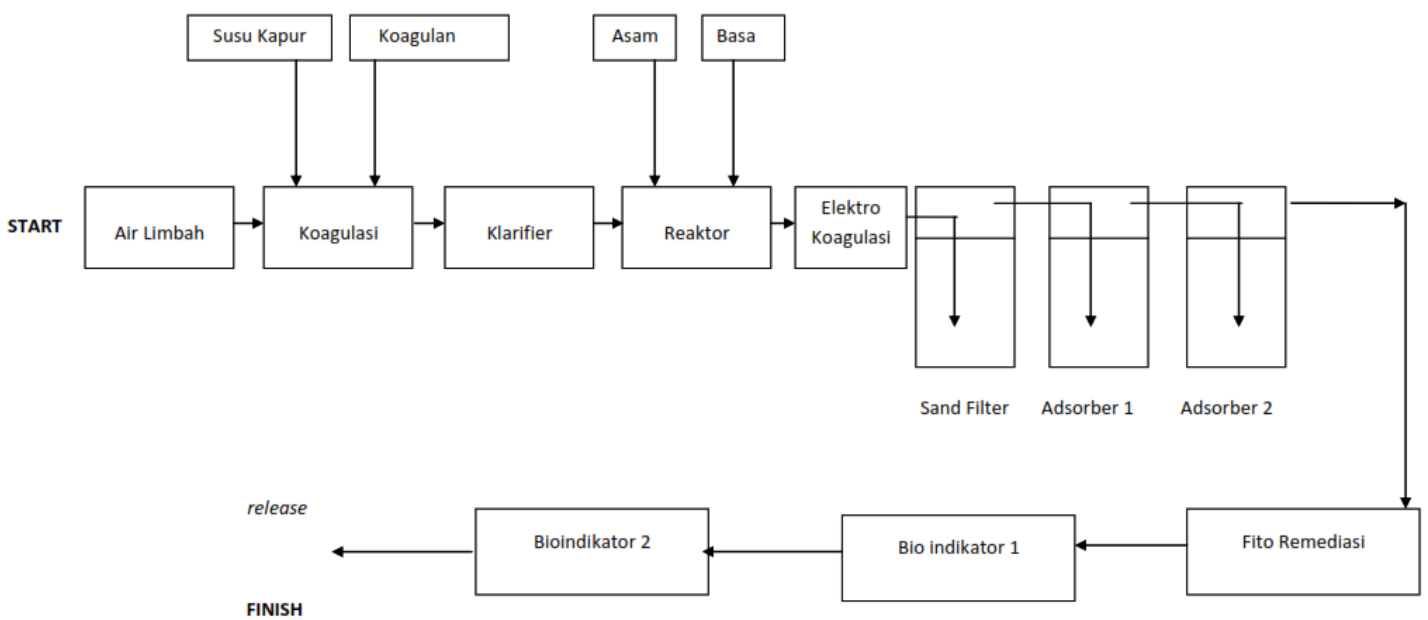

Gambar 1. Diagram Alir Alat Olah Limbah Cair Laboratorium

Penelitian ini dilakukan di Politeknik Negeri Cilacap. Sejumlah Laboratorium Teknologi Lingkungan volume air limbah dinetralisasi kemudian 
dilakukan proses filtrasi dan koagulasi menggunakan kapur, dan tawas. Tahap selanjutnya limbah laboratorium dilakukan proses koagulasi, elektrokoagulasi, dan filtrasi kemudian limbah diproses menggunakan metode fitoremediasi. Fitoremediasi menggunakan tanaman air: kangkung, enceng gondok dan semanggi. Keseluruhan proses ini menghasilkan filtrat sebagai by-product.

Tahapan akhir berupa imobilisasi produk samping menjadi batu bata yang bertujuan untuk memperangkap senyawa pada produk samping pada pengolahan limbah serta menambah estetika alami.

Filtrat yang terbentuk dijadikan batu bata semen dengan komposisi rasio limbah dan pozzolanik adalah $1: 1,1: 2$ dan 1 : 3 dengan proses pencampuran hingga homogen, serta metode skenario isolasi limbah (limbah diisolasi dan tanpa diisolasi). Metode uji yang digunakan dalam kegiatan pengujian kualitas air lindi batu bata menggunakan metode Standar Nasional Indonesia (SNI) bidang lingkungan kualitas air dan air limbah. Parameter uji yang dipantau ada dua kategori yaitu parameter uji fisika, dan parameter uji kimia. Metode Pengujian untuk berbagai parameter disajikan dalam Tabel 1.

Tabel 1. Metode Pengujian untuk Parameter Kualitas Air Leaching

\begin{tabular}{ll}
\hline \multicolumn{1}{c}{ Parameter } & \multicolumn{1}{c}{ Spesifikasi Metode } \\
\hline $\begin{array}{l}\text { Suhu } \\
\text { Jumlah zat padat terlarut }\end{array}$ & SNI 06-6989.23-2005 \\
(TDS) & \\
Zat padat tersuspensi & SNI 06-6989.27-2005 \\
(TSS) & \\
pH & SNI 06-6989.11-2004 \\
Mangan & SNI 6989.5-2009 \\
Tembaga & SNI 6989.6-2009 \\
Seng & SNI 6989.7-2009 \\
Krom $(\mathrm{VI})$ & SNI 6989.71-2009 \\
Kadmium $(\mathrm{Cd})$ & SNI 6989.16-2009 \\
Timbal $(\mathrm{Pb})$ & SNI 6989.8-2009 \\
\hline
\end{tabular}

\begin{tabular}{lc}
\hline Kobalt $(\mathrm{Co})$ & SNI 6989.68-2009 \\
Fluorida & IKM CLCP-08 \\
Klorin Bebas $\left(\mathrm{Cl}_{2}\right)$ & IKM CLCP-12 \\
Nitrit sebagai N & SNI 06-6989.9-2004 \\
BOD $_{5}$ & SNI 6989.72-2009 \\
COD SNI 6989.73-2009 \\
\hline \multicolumn{2}{c}{ Pada tahap interpretasi hasil dan } \\
simpulan dilakukan identifikasi hasil batu \\
bata dengan uji laboratorium sehingga \\
didapatkan interpretasi kondisi optimal. \\
Metode uji dalam kegiatan pengujian \\
kualitas air perlindian batu bata mengacu \\
pada Standar Nasional Indonesia (SNI) \\
bidang lingkungan kualitas air dan air \\
limbah.
\end{tabular}

Data yang diperoleh dari uji laboratorium dilakukan pengolahan dalam bentuk tabel atau grafik, untuk mengetahui efektifitas metode imobilisasi pada hasil samping limbah menjadi batu bata.

\section{HASIL PENELITIAN}

Laboratorium Kimia Teknik Pengendalian Pencemaran Lingkungan adalah laboratorium yang melayani kegiatan praktik mahasiswa, sehingga air limbah yang dihasilkan juga kaya akan senyawa kimia beracun. Berdasarkan Peraturan Pemerintah Republik Indonesia No. 101 Tahun 2014 Pasal 3 menyatakan bahwa setiap orang yang menghasilkan limbah B3 wajib melakukan pengelolaan limbah B3 yang dihasilkannya. Pengelolaan limbah B3 tersebut diupayakan menggunakan teknologi bersih. Pengolahan air limbah laboratorium termasuk dalam kategori pengelolaan limbah.

Penerapan teknologi produksi bersih pada sistem IPAL mengakibatkan terjadinya perubahan secara fisika, kimia dan karakteristik air limbah tersebut. Karakteristik air limbah yang dihasilkan diharapkan terjadinya pengurangan 
polutan organik terlarut dan polutan tersuspensi. Usaha-usaha yang perlu dilakukan untuk mengantisipasi kerusakan lingkungan akibat limbah yang dihasilkan antara lain melalui perbaikan sistem pembuangan limbah yang memadai dengan teknologi pengolah limbah yang bersifat ramah lingkungan (Rina dkk., 2011). Teknologi tersebut diharapkan metode atau teknik pengolahan limbah yang inovatif, murah dan efektif dalam menurunkan parameter-parameter pencemar sebelum limbah cair tersebut dibuang ke lingkungan (Wardhani dkk., 2012).

Teknik-teknik pengolahan limbah secara umum terbagi menjadi 3 metode pengolahan yaitu pengolahan secara fisika, secara kimia dan secara biologi. Untuk suatu jenis limbah tertentu, metode pengolahannya dapat diaplikasikan secara terpisah atau kombinasi dari metode yang dikembangkan. (Widjajanti. 2009).

Metode terbaru dalam pengolahan IPAL yaitu metode bioremediasi dan elektrokoagulasi. Pada metode elektrokoagulasi, semakin besar kuat arus maka semakin lama pula waktu proses dan semakin kecil jarak elektrode maka semakin besar penurunan konsentrasi COD, TSS, dan alkalinitas (Prayitno dkk., 2016).

Konsep penggabungan pengolahan limbah cair laboratorium sangat dimungkinkan dengan prinsip green technology. Mekanismenya adalah memilih bahan baku dan rute proses yang menghasilkan limbah sedikit tetapi dapat dimanfaatkan kembali secara berkesinambungan serta memilih material yang polutif ke non polutif (Bhardwaj, 2015).

Pada penelitian yang dilakukan, air limbah ditreatment menggunakan alat pengolah air limbah. Bagian utama dari desain alat pengolahan air limbah laboratorium terdiri dari: tangki koagulasi, tangki netralisasi, tangki elektrokoagulasi, tabung penyaring, tabung yang berisi zeolit dan karbon aktif, serta kolam fitoremediasi. Masing-masing bagian mempunyai fungsi dan kegunaan yang berbeda. Pada tangki koagulasi, dan tangki elektrokoagulasi akan dihasilkan endapan. Selanjutnya air limbah laboratorium melewati proses penyerapan dengan zeolit dan karbon aktif. Hasil pengolahan air limbah tersebut dialirkan menuju kolam fitoremediasi yang berfungsi sebagai penyerap zat-zat yang masih tersisa dalam limbah, waktu tinggal yang terjadi ditangki fitoremediasi dan selanjutnya air limbah akhir dialirkan dalam kolam bioindikator. Hasil filtrat kemudian dikumpulkan untuk dilakukan treatment imobilisasi.

Hasil akhir yang diharapkan pada IPAL adalah berupa produk cair yang sudah memenuhi baku mutu air limbah. Untuk produk samping (by-product) dari IPAL adalah berupa padatan. Padatan ini masih mengandung kontaminan bahan pencemar. Imobilisasi dengan cara solidifikasi adalah salah satu alternatif untuk mengelola produk samping berupa sludge tersebut. Metode imobilisasi ini dilakukan dengan cara menambahkan pengikat semen, seperti kapur dan semen, diharapkan senyawa beracun yang ada pada limbah akan stabil secara fisik dan kimia sehingga meminimalkan ancaman terhadap lingkungan (Dermatas, 2003).

Proses imobilisasi pada prinsipnya adalah mengurangi mobilitas bahan pencemar didalam limbah, dilakukan dengan cara mengubah sludge menjadi bentuk yang kompak, tidak berbau dan tidak mengandung mikroorganisme yang mengganggu kesehatan serta bahan-bahan 
pencemar yang berada di dalamnya tidak mudah mengalami perlindian (leached).

Perlakuan proses imobilisasi sludge tersebut dilakukan dengan lima perlakuan yang dapat dilihat pada tabel 2. Berikut :

Tabel 2. Perlakuan Imobilisasi Sampel

\begin{tabular}{|c|c|c|c|}
\hline \multirow[t]{2}{*}{ Sampel } & \multicolumn{2}{|c|}{ Komposisi Rasio } & \multirow{2}{*}{ Keterangan } \\
\hline & Pozzolanik & Sludge & \\
\hline A & 1 & 1 & Sludge tercampur merata dengan pozzolanik \\
\hline B & 2 & 1 & Sludge tercampur merata dengan pozzolanik \\
\hline $\mathrm{C}$ & 3 & 1 & Sludge tercampur merata dengan pozzolanik \\
\hline D & 2 & 1 & $\begin{array}{l}\text { Pozzolanik tidak tercampur dengan sludge, tetapi } \\
\text { pozzolanik menyelimuti sludge (sludge terperangkap } \\
\text { ditengah pozzolanik) }\end{array}$ \\
\hline $\mathrm{E}$ & 2 & 1 & $\begin{array}{l}\text { Pozzolanik tidak tercampur dengan sludge, tetapi } \\
\text { pozzolanik menyelimuti sludge yang terisolasi } \\
\text { dalam wadah tertutup (sludge terperangkap ditengah } \\
\text { pozzolanik). }\end{array}$ \\
\hline
\end{tabular}

Setelah dilakukan imobilisasi sludge dilakukan uji perlindian. Adapun laboratorium kimia dapat dilihat pada tabel 3. berikut ini: hasil uji air perlindian batu bata limbah

Tabel 3. Hasil Uji Air Perlindian Imobilisasi Sampel Batu Bata

\begin{tabular}{|c|c|c|c|c|c|c|c|c|}
\hline \multirow{2}{*}{ Parameter } & \multirow{2}{*}{ Satuan } & \multicolumn{5}{|c|}{ Sampel } & \multicolumn{2}{|c|}{ Baku Mutu*) } \\
\hline & & $\mathbf{A}$ & B & $\mathrm{C}$ & D & $\mathbf{E}$ & $\mathbf{I}$ & II \\
\hline Suhu & ${ }^{\circ} \mathrm{C}$ & 29,1 & 23,6 & 23,7 & 27,3 & 22,9 & 38 & 40 \\
\hline $\begin{array}{l}\text { Jumlah zat padat } \\
\text { terlarut (TDS) }\end{array}$ & $\mathrm{mg} / \mathrm{l}$ & 4200 & 812 & 638 & 792 & 728 & 2000 & 4000 \\
\hline $\begin{array}{l}\text { Zat padat } \\
\text { tersuspensi (TSS) }\end{array}$ & $\mathrm{mg} / \mathrm{l}$ & 47 & 10 & $<2,5$ & 12 & 4 & 200 & 400 \\
\hline pH & - & 9,26 & 9,54 & 9,48 & 8,35 & 9,91 & $6,0-9,0$ & $6,0-9,0$ \\
\hline Mangan & $\mathrm{mg} / \mathrm{l}$ & $<0,026$ & $<0,026$ & $<0,026$ & 0,03 & $<0,026$ & 2 & 5 \\
\hline Tembaga & $\mathrm{mg} / \mathrm{l}$ & $<0,058$ & $<0,058$ & $<0,058$ & $<0,058$ & $<0,058$ & 2 & 3 \\
\hline Seng & $\mathrm{mg} / \mathrm{l}$ & $<0,014$ & 0,08 & $<0,014$ & $<0,014$ & $<0,014$ & 5 & 10 \\
\hline $\operatorname{Krom}(V I)$ & $\mathrm{mg} / \mathrm{l}$ & 0,096 & $<0,04$ & 0,03 & $<0,004$ & $<0,004$ & 0,1 & 0,5 \\
\hline Kadmium (Cd) & $\mathrm{mg} / \mathrm{l}$ & $<0,014$ & $<0,014$ & $<0,014$ & $<0,014$ & $<0,014$ & 0,5 & 1 \\
\hline Timbal (Pb) & $\mathrm{mg} / \mathrm{l}$ & $<0,251$ & $<0,251$ & $<0,251$ & $<0,251$ & $<0,251$ & 0,1 & 1 \\
\hline Kobalt (Co) & $\mathrm{mg} / \mathrm{l}$ & $<0,061$ & $<0,061$ & $<0,061$ & $<0,061$ & $<0,061$ & 0,4 & 0,6 \\
\hline Fluorida & $\mathrm{mg} / \mathrm{l}$ & 0,12 & 0,52 & 0,59 & 0,15 & 0,42 & 2 & 3 \\
\hline Klorin Bebas $\left(\mathrm{Cl}_{2}\right)$ & $\mathrm{mg} / \mathrm{l}$ & 0,22 & 0,05 & 0,17 & 0,17 & 0,06 & 1 & 2 \\
\hline Nitrit sebagai N & $\mathrm{mg} / \mathrm{l}$ & 0,07 & 0,01 & 0,05 & 0,02 & 0,06 & 1 & 3 \\
\hline BOD $_{5}$ & $\mathrm{mg} / \mathrm{l}$ & 26,04 & 14,63 & 9,23 & 5,3 & 8 & 50 & 150 \\
\hline COD & $\mathrm{mg} / \mathrm{l}$ & 46,78 & 25,95 & 12,21 & 9,36 & 15,27 & 100 & 300 \\
\hline
\end{tabular}

*) Lampiran XLVII Permen LH RI No.5 Tahun 2014 Tentang Baku Mutu Air Limbah Bagi Usaha Kegiatan yang Belum Memiliki Baku Mutu Air Limbah yang Ditetapkan 


\section{PEMBAHASAN}

Berdasarkan tabel 3. diketahui bahwa yang tidak memenuhi baku mutu untuk parameter jumlah zat padat terlarus (TDS) untuk sampel A sebesar 4200 mg/l. Hal ini disebakan oleh lolosnya zat organik dan anorganik dalam bentuk molekul yang terionkan atau mikrogranula yang terperangkap. Komposisi pozzolanik dengan sludge 1: 1 masih memungkinkan migrasinya ion-ion sludge pada badan air hal ini dikarenakan kurangnya kemampuan pozzolanik untuk mengikat atau mengisolasi ion-ion tersebut dipermukaan batubata. Sludge yang masih memiliki akadar air yang tinggi akan menyebabkan rasio antara bahan pozzolanik dan air menjadi lebih tinggi. Rasio air - semen merupakan hal yang penting dalam proses imobilisasi karena akan mempengaruhi ukuran pori dan perubahan volume. Rasio air - semen yang rendah akan menyebabkan ukuran pori yang kecil. Pori yang kecil merupakan hal penting dalam proses imobilisasi, karena kontaminan akan terjebak di dalamnya sehingga mobilitasnya dalam limbah akan berkurang (Prajanto, 2007).

Parameter $\mathrm{pH}$ untuk keempat sampel ( A,B,C, dan E) melampaui baku mutu yang ditetapkan diatas $\mathrm{pH} 9$, hal ini disebabkan oleh sifat semen itu sendiri yang cenderung basa. Imobilisasi berbasis pozzolan efektif digunakan untuk limbah B3 dengan $\mathrm{pH}$ rendah karena mampu menetralisir asam (Wami, 2015).

Pada proses imobilisasi yang dilakukan bertujuan untuk menurunkan laju migrasi bahan pencemar dari sludge sehingga mengurangi toksisitas limbah tersebut. Laju tersebut dibatasi oleh struktur yang kokoh/kekar (massive) dengan membentuk ikatan massa monolit.
Bahan tambahan pada proses ini menggunakan bahan yang bersifat pozzolanik sebagai binder atau pengikat. Proses tersebut menyebabkan kontaminan akan teradsorpsi sehingga secara elektrokimiawi kontaminan tersebut terikat dengan binder dalam matriks. Ikatan ini terjadi melalui ikatan hidrogen. Kontaminan yang telah teradsorpsi oleh matriks menyebabkan zat yang terkandung dalam kontaminan tersebut lebih sulit untuk terlepas ke lingkungan dibandingkan kontaminan yang tidak teradsorpsi.

Secara fisik bahan kontaminan dari limbah B3 dapat diikat oleh bahan pengabsorpsi. Bahan absorben harus memiliki sifat pozzolanik untuk mengikat kontaminan yang bersifat cair. Kontaminan yang telah diikat akan berubah bentuk menjadi keras sehingga dapat disimpan lebih lama (Trihadiningrum, 2016).

Unsur-unsur silika dan alumina atau kombinasi keduanya merupakan bahan yang bersifat pozzolanik (Wami, 2015).

Semen merupakan bahan yang sering digunakan sebagai bahan pengikat pada imobilisasi yang mampu untuk menahan ion-ion (Castelo, 2003). Semen sebagai pozzolan untuk imobilisasi terhadap logam berat $\mathrm{Pb}$ menyebabkan $\mathrm{Pb}$ terperangkap di dalam matriks semen dan terkonversi menjadi bentuk yang stabil secara fisik maupun secara kimia (Cocke, 1990)

Secara umum semua perlakuan imobilisasi by-product dari alat olah limbah laboratorium yang berupa sludge berdasarkan metode perlindian telah memenuhi baku mutu yang dipersyaratkan. Hal ini membuktian bahwa laju migrasi dan toksisitas dari kontaminan yang terdapat pada sludge 
berkurang akibat terikatnya kontaminan menyebabkan berubahnya sifat fisik sludge limbah.

\section{KESIMPULAN DAN SARAN}

Berdasarkan hasil analisis yang berpedoman pada Lampiran XLVII Permen LH RI No.5 Tahun 2014 Tentang Baku Mutu Air Limbah Bagi Usaha Kegiatan yang Belum Memiliki Baku Mutu Air Limbah yang Ditetapkan, dari 16 (enambelas) parameter yang diujikan terdapat 2 (dua) parameter yang tidak memenuhi baku mutu.

Untuk parameter jumlah zat padat terlarut (TDS) untuk sampel A sebesar $4200 \mathrm{mg} / \mathrm{l}$. Komposisi pozzolanik sebagai binder dengan sludge 1 : 1 masih memungkinkan migrasinya ion-ion sludge pada badan air hal ini dikarenakan kurangnya kemampuan pozzolanik untuk mengikat atau mengisolasi ion-ion tersebut dipermukaan batubata.

Parameter $\mathrm{pH}$ untuk keempat sampel ( $\mathrm{A}, \mathrm{B}, \mathrm{C}$, dan E) melampaui baku mutu yang ditetapkan, hal ini disebabkan oleh sifat semen itu sendiri yang cenderung basa.

Batu bata yang dibuat berdasarkan rasio binder dan sludge adalah $1: 1,2: 1$ atau $3: 1$.

Penyimpanan by-product (sludge) alat olah limbah laboratorium kimia pendidikan dalam bentuk batu bata semen aman dilakukan.

\section{DAFTAR RUJUKAN}

Bhardwaj M, Neelam. 2015. The Advantages and Disadvantages of Green Technology. Journal of Basic and Applied Engineering Research 2(22): 1957-1960.

Castelo-Grande T., Barbosa D. 2003. Soil Decontamination by supercritical
Extraction. Electronic Journal of Environmental, Agricultural, and Food Chemistry 2, 2: 331-336.

Cocke, D. L. 1990. The Binding Chemistry and Leaching Mechanisms of Hazardous Substances in Cementitious Solidification /Stabilization Systems. Journal of Hazardous Materials 24; 231-253.

Dermatas, D. dan Meng, X. 2003. Utilization of fly ash for stabilization/solidification of heavy metal contaminated soils. Engineering Geology 70: 377-394.

Peraturan Pemerintah Republik Indonesia No. 101 Tahun 2014 Tentang Pengelolaan Limbah Bahan Berbahaya dan Beracun

Pranjoto, M.U., Endang W.L., 2007. Kajian Tentang Proses Solidifikasi/Stabilisasi Logam Berat dalam Limbah dengan Semen Portland. Prosiding Seminar Nasional Penelitian, Pendidikan dan Penerapan MIPA. Yogyakarta.

Prayitno, Rulianah S, Takwanto A. 2016. Pengolahan Air Limbah Laboratorium Menggunakan Proses Elektrokoagulasi. Seminar Nasional Terapan Riset Inovatif. Semarang

Rina. S. Soetopo, Sri Purwati, Yusup Setiawan, Krisna Adhytia.W. 2011. Efektivitas Proses Kontinyu Digestasi Anaerobik Dua Tahap Pada Pengolahan Lumpur Biologi Industri Kertas. Jurnal Riset Industri 5 (2) : 131-142

Trihadiningrum, Y. 2016. Pengelolaan Limbah Bahan Berbahaya dan Beracun. Teknosain, Yogyakarta.

Wami, E. N., dan Nmegbu, C. G. J. 2015. Micro-EncapsulationTechnique for Effective Remediation of Hydrocarbon Contaminants 
.International Journal of Scientific \& Engineering Research 6, 8: 815-823.

Wardhani E, Dirgawati M, Valyana KP. 2012. Penerapan Metode Elektrokoagulasi Dalam Pengolahan Air Limbah Industri Penyamakan Kulit. Seminar Ilmiah Nasional Penelitian Masalah Lingkungan di Indonesia Universitas Gadjah Mada: Yogyakarta.

Widjajanti E. 2009. Penanganan Limbah Laboratorium Kimia. Jurusan Pendidikan Kimia FMIPA UNY. Disajikan dalam Kegiatan PPM Prodi Pendidikan Kimia, 13 Nopember 2009. 